\title{
SCIENTIFIC ETHOS AND THE CINEMATIC ZOMBIE OUTBREAK

\author{
SCIENCE IN FICTIONAL NARRATIVES
}

\section{LEAH CECCARELLI}

Public anxiety about emerging biothreats is evident in the recent glut of popular entertainment where the demise, or near demise, of humankind is imagined to be the result of a new infectious pathogen against which science has no existing vaccine or cure. This article examines the figure of the scientist in such fictional narratives and what these characterizations indicate about public attitudes toward science in our contemporary world. It focuses in particular on the image of the scientist as clumsy naïve, immoral experimenter, heroic savior, and self-reflexive ethical agent.

Keywords: rhetoric of science, frontiers of science, science fiction, public attitudes toward science.

The twenty-first century has seen a surge in zombie movies. A number of explanations have been offered for this outbreak of apocalyptic narratives featuring hordes of the undead and the breakdown of civilization. The rise of the genre is said to reflect xenophobic anxiety about immigration and the fecund reproduction of the dark «Other» in a so-called «postracial» era (Watts, 2014). The cannibalistic hunger of the zombie is said to reflect the abject mindlessness of our excessive and irresponsible consumption in a period of ever-accelerating global capitalism (Boluk \& Lenz, 2010). Our empathy with the mechanics of zombie-killing is said to come from our daily dispatch of the avalanche of tedious emails, Twitter feeds, and blog updates that threaten to overwhelm us in this internet age (Klosterman, 2010). Undoubtedly, all of these explanations are accurate.

But there is another explanation suggested by a key difference between the zombies of our cinematic past and the twenty-first century zombies that are overrunning our theatres. The zombies of early cinema pointed to racial anxieties because their origins lie in rituals of voodoo witchcraft (Halperin \& Halperin, 1932). The Cold War era zombies of George Romero's classic Night of the living dead (Romero, Hardman, \& Streiner, 1968) were imagined to be the result of radiation from a space probe, reflecting cultural anxieties about space exploration and nuclear fallout. In contrast, today's cinematic zombies are imagined to be the result of viral pandemics. In

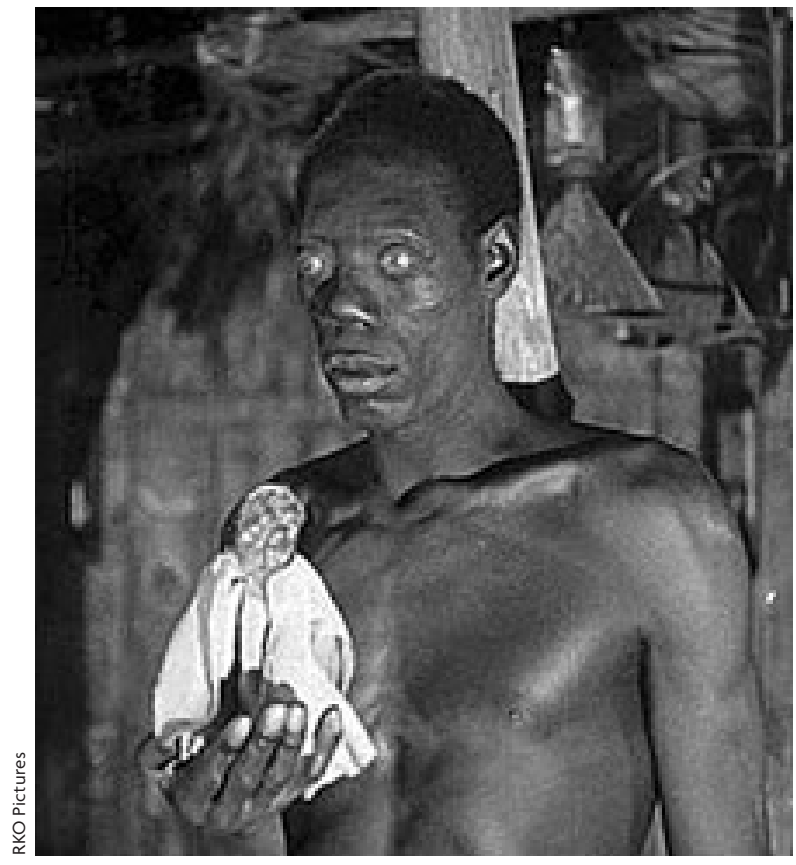

The zombies of early cinema pointed to racial anxieties. In the picture, a still from I walked with a zombie (1934), by Jacques Tourneur.

\footnotetext{
"THE ZOMBIES OF EARLY CINEMA POINTED TO RACIAL ANXIETIES BECAUSE THEIR ORIGINS LIE IN RITUALS OF VOODOO WITCHCRAFT"
} 
contemporary cinematic narratives, zombies are created by the release of a novel and highly infectious pathogen against which science has no vaccine or cure, a disease so deadly and contagious that civilization collapses in its wake.

In light of this difference between the zombie narratives of the past and present, there is an argument to be made that the contemporary zombie film reflects a straightforward fear of a viral pandemic in our current era, revealing our anxiety about both the power and the ineffectiveness of modern biomedical sciences. In this article, I offer a close reading of three recent movies that tell the story of fast-moving, virus-infected zombies and the collapse of civilization. These movies are not intended to represent all contemporary zombie narratives; they are just three revealing examples. My interest in examining these movies is not just to highlight the fear of contagious disease that they reflect and promote among an increasingly mobile and interconnected global population in an age of bioscience, but to tease out the specific way in which each movie portrays the figure of the scientist. As German sociologist Peter Weingart (2003) suggests, the ethos of the scientist developed through «images, clichés, and metaphors» in fictional film can tell us much about the relationship between science and society. So what does the portrayal of the scientist in contemporary zombie movies tells us about the way we think about scientists in our modern world?

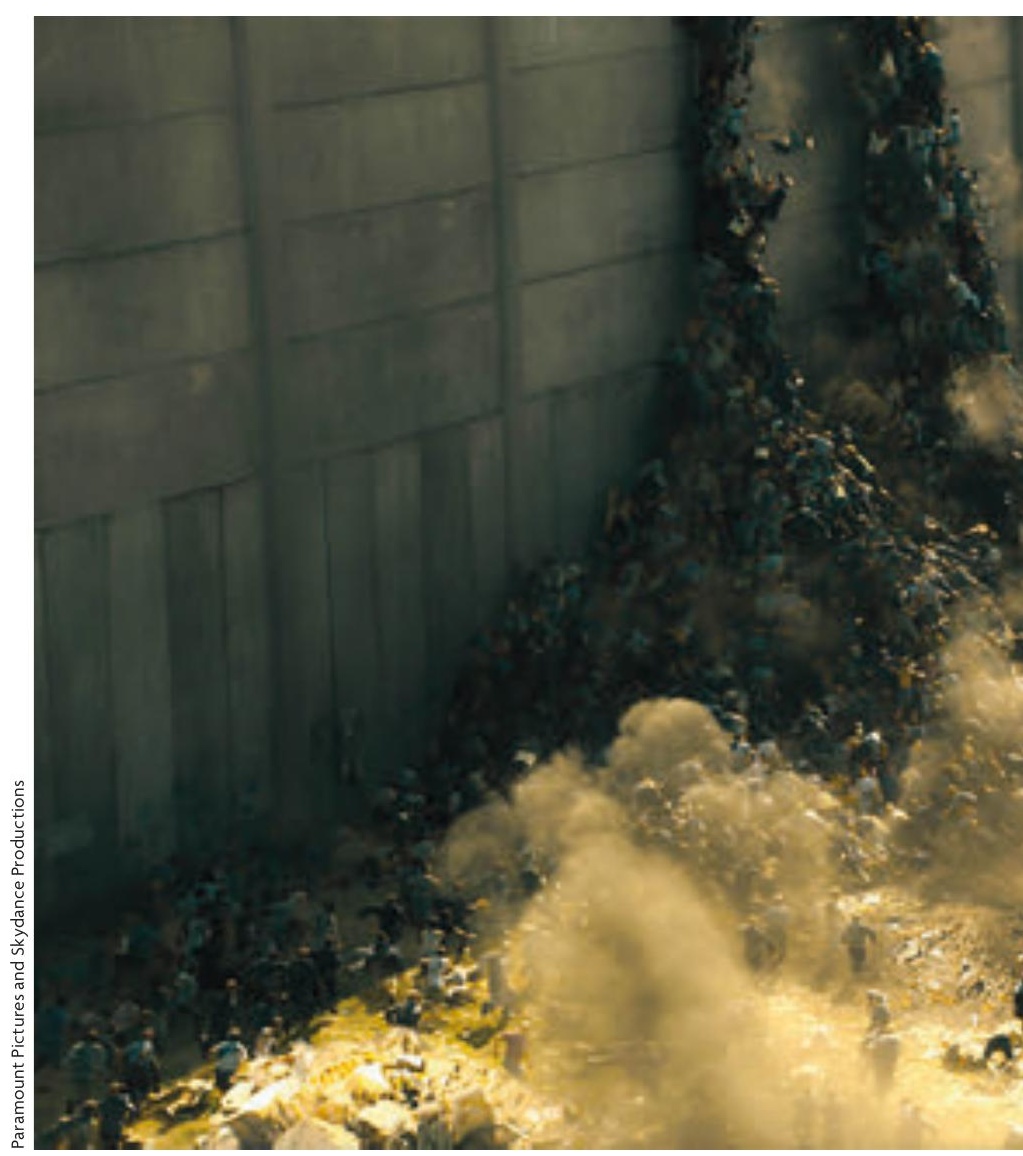

The Cold War era zombies of George Romero's classic Night of the living dead (below these lines) were imagined to be the result of radiation from a space probe, reflecting cultural anxieties about space exploration and nuclear fallout.

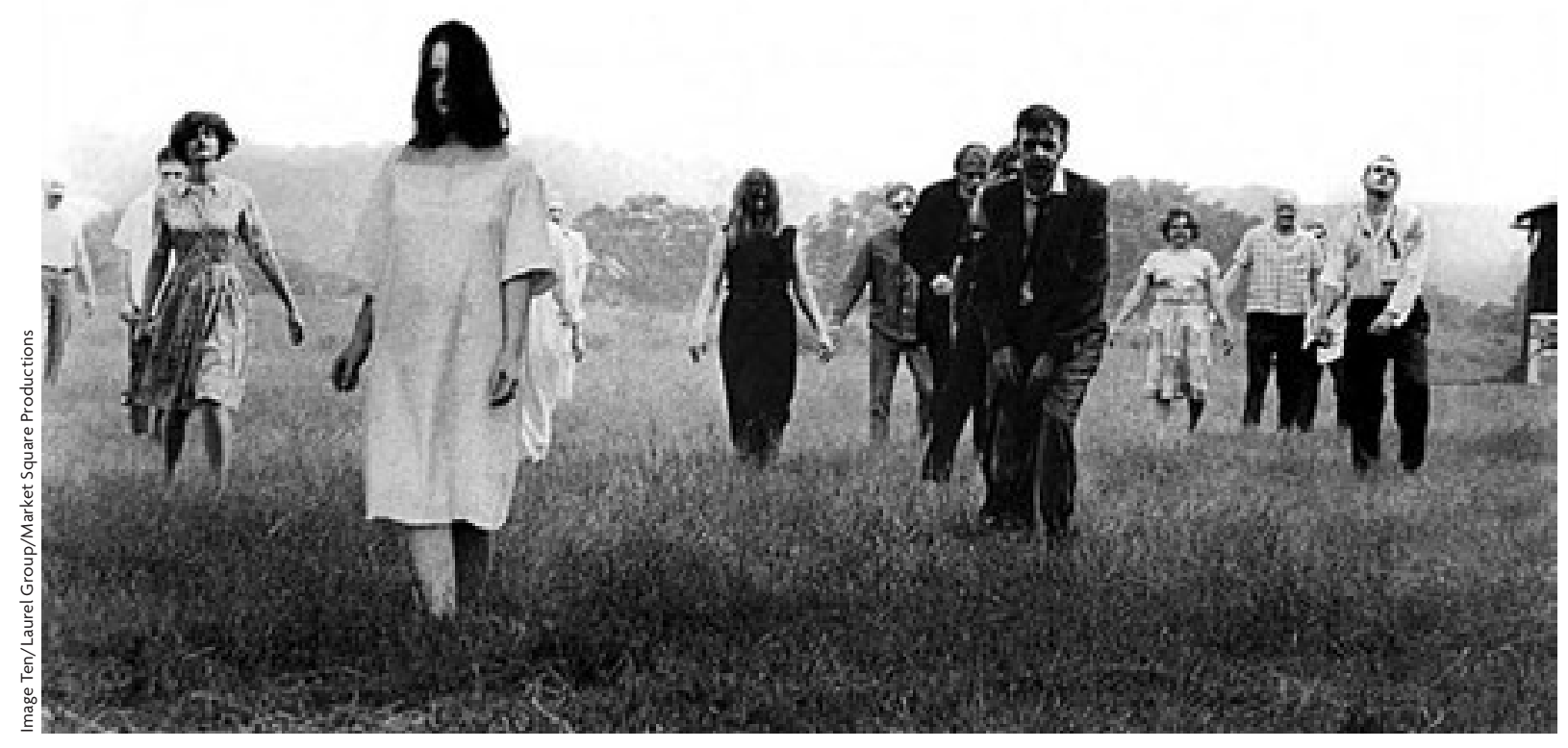




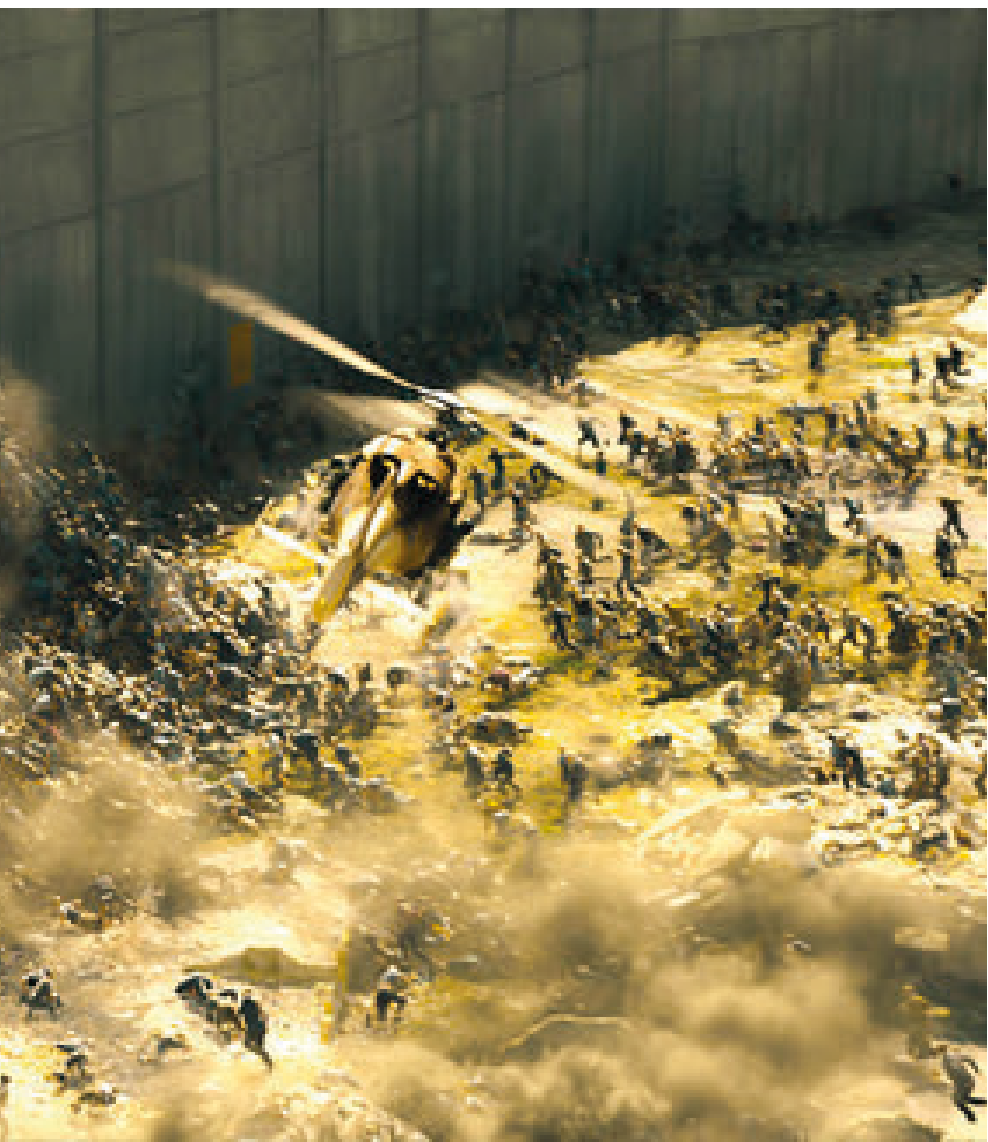

I ask this question having recently written a book about the way contemporary American scientists portray themselves when they directly address the public in speeches and popular texts (Ceccarelli, 2013). I found that when these scientists construct their public ethos, they like to imagine themselves through the figure of the frontiersman - as heroic, fiercely independent men, who courageously enter new knowledge territory to stake a claim to what they discover out there, «on the frontier of science.» So are scientists portrayed similarly in recent cinematic narratives produced by nonscientists?

'WORLD WAR Z': THE SCIENTIST AS CLUMSY, NAIIVE, AND WORSE THAN USELESS

As it turns out, the contemporary zombie movie does bear some striking similarities to the classic

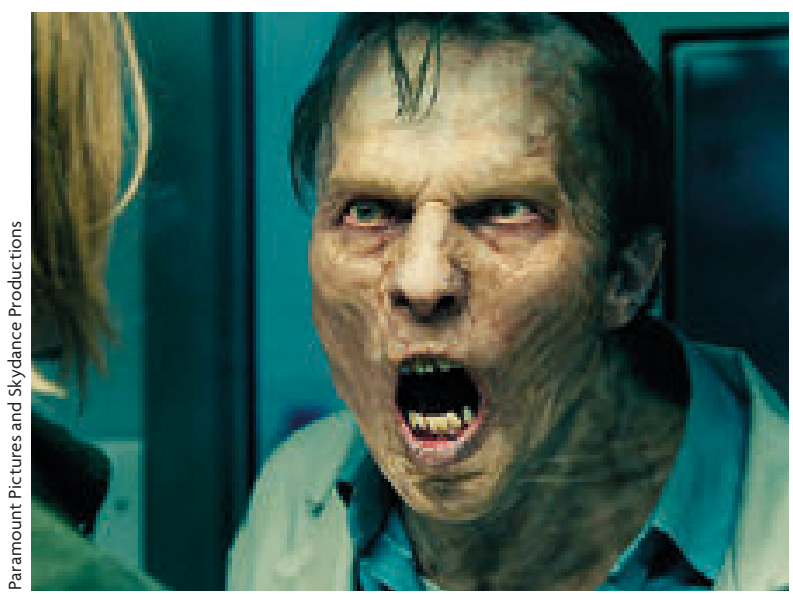

A number of explanations have been offered for this outbreak of apocalyptic narratives featuring hordes of the undead and the breakdown of civilization. The rise of the genre is said to reflect xenophobic anxiety about immigration and the fecund reproduction of the dark "Other" in a so-called "post-racial" era. On the left and above, stills from the film World War Z (2013).

western film, with gun-toting heroes facing off against hostile savages. But scientists are rarely the protagonists of these narratives, occupying the role of the foolish victim instead. For example, consider the recent blockbuster World War Z, where scientists are represented as the opposite of the heroic frontiersman, appearing as clumsy naïves who are ineffectual and dangerous to themselves and others (Forster, Bryce, Gardner, Kleiner, \& Pitt, 2013).

The first scientist introduced in this film is Dr. Fassbach, a virologist from Harvard who is initially described as «our best bet» at overcoming the zombie pandemic that has swiftly overtaken the world. The real hero of the movie, United Nations investigator Gerry Lane (played by Brad Pitt), is skeptical, saying «he's just a kid». Against his better judgment, the reluctant gunslinger, Lane, is forced out of retirement to accompany the tenderfooted youngster into the dangerous zombiefilled wildlands.

The adventure does not start out well, as Dr. Fassbach proves to be an incompetent virus hunter. As soon as they enter the danger zone, zombies attack, and in the virologist's rush to flee back into the safety of the military plane, he trips on the ramp and accidentally shoots himself in the head, dying instantly. So much for Dr. Fassbach. 
Toward the end of the movie, the audience is introduced to another scientist at a World Health Organization compound; this individual is likewise characterized as dangerously clumsy. We see a video in which Dr. Spellman, the chief vaccinologist of the laboratory, contaminates himself with the virus by accidentally cutting his hand while working with a blood sample. He immediately turns into a zombie, and then infects all eighty people working in his wing of the compound.

In the end, it is Lane who carries out the mission of figuring out how to defeat the virus. Acting as a sort of citizen scientist on the frontiers of knowledge, Lane makes field observations of zombies ignoring people dying of other diseases and concludes that zombies detect and avoid people who are seriously ill. So he courageously infects himself with a horrible pathogen that camouflages him from the zombies and thus demonstrates the strategy that will ultimately win the zombie war for humanity. No credentialed scientist makes this great discovery; instead, it is the reluctant gunslinger, a United Nations investigator who is calm enough in battle to notice the little things, and thus has what it takes to save humankind.

'28 DAYS LATER': THE SCIENTIST AS VICTIM OF HIS OWN IMMORAL EXPERIMENTS

If World War Z presents the image of the scientist as blundering fool, the next movie I would have us consider presents the closely related image of the scientist as helpless victim, unable to control the outcome of his own ethically questionable work. Both are popular archetypes of the scientist identified by science and literature scholar Roslynn Haynes (2003). When you consider the fact that the zombie apocalypse narrative draws its drama from the breakdown of civilization's most trusted institutions, there is a certain logic to portraying scientists in this manner.

The scientist as victim of his own experiments is a theme introduced early in Danny Boyle's 28 days later (Boyle \& Macdonald, 2002), one of the earliest zombie pandemic films of the twenty-first century. At the beginning of the film, three animal rights activists in ski masks break into a science laboratory where chimpanzees are the subjects of horrifying experiments. A scrawny scientist walks in on the

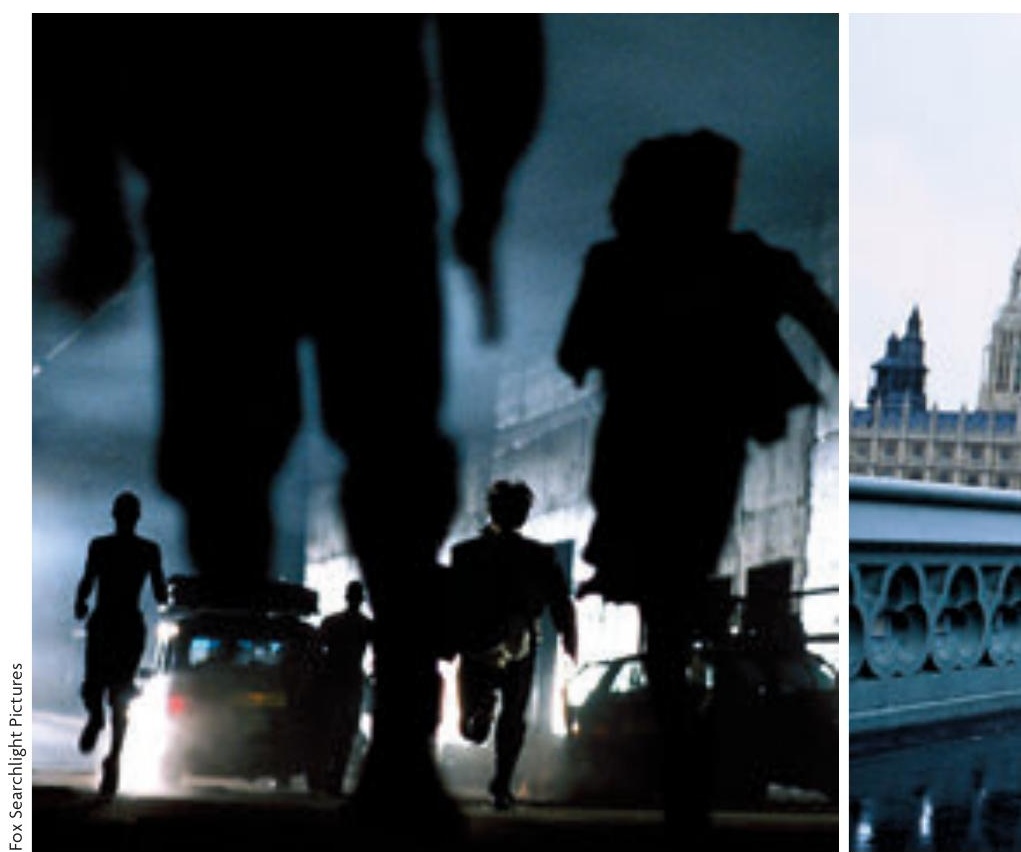

activists as they prepare to free the animals and stutters out a warning: «the chimps are infected. They're highly contagious». He then offers an unsolicited justification for his treatment of these animals: «In order to cure, you must first understand».

It turns out that the chimps had been infected with «Rage», a virus that is passed through bodily fluids and causes the infected to violently attack the uninfected, and thus pass on the virus to others. As soon as the activists release a chimp, it immediately attacks them, and in moments, they and the hapless scientist are Rage-infected zombies.

Twenty-eight days after this incident, the city of London is a desolate wasteland, populated only by a few lonely survivors and roving bands of Rage zombies. The parallels between the zombie apocalypse film and the classic western genre are particularly clear in these scenes. London is a densely populated city, so one would expect an equally high density of Rage zombies to be roaming its streets. Yet somehow, the main character, Jim, upon waking from a coma, is able to wander the deserted streets for several minutes before encountering any zombies. Luckily, when the zombies do appear, he gets saved by a couple of machete- and gun-toting survivors who teach him how to live in this hostile new environment. 


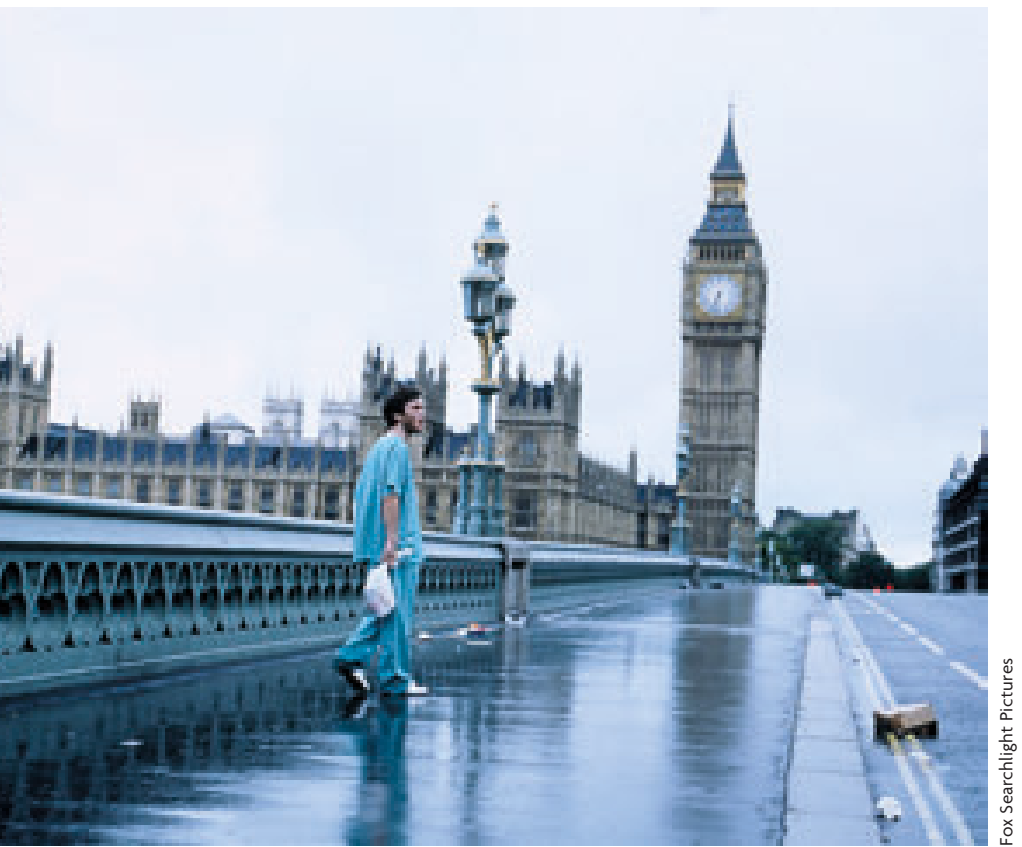

Our contemporary fear of viral apocalypse is thus tied to our ambivalence about scientists, who can be figures of scorn or worship, both the cause of the coming catastrophe and the source of our salvation. Above, stills from 28 days later (2002), in which the protagonist wakes up from a coma to a city devastated by a virus after a group of infected chimpanzees were liberated. is represented as the opposite of how scientists in the film behave. Does this mean that the image of scientist as frontier hero that scientists are so fond of projecting in their public communications is not reflected in popular culture's representations of scientists? Well, yes and no. A third recent popular film constructs the ethos of scientists as something closer to how scientists like to represent themselves.

\section{‘I AM LEGEND’: SCIENTIST AS FRONTIERSMAN}

The stereotype of the scientist as frontiersman exists in a cinematic merger of two other archetypes that Haynes identifies in science fiction literature: the scientist as adventurer and the scientist as hero, or savior, of society. This vision of the scientist is found in I am legend (Lawrence, Goldsman, Heyman, Lassiter, \& Moritz, 2007), a blockbuster with Will Smith as the title character, Robert Neville, a world famous scientist who also happens to be a highranking military officer with a ripped physique.

Another scientist representing the overconfident soon-to-be victim is introduced in the opening scenes of the movie. Dr. Alice Krippin, played by Emma Thompson, is interviewed about the cure for cancer that she has created from a genetically engineered measles virus. Her obvious pride at creating this miracle cure is undercut by the post-apocalyptic scene that follows the title card «three years later». We come to learn that the Krippin virus has mutated into a dangerous pathogen with a $90 \%$ «kill rate». Less than $1 \%$ of the population had a natural immunity, and the remainder were turned into «dark seekers», fast-moving athletic zombies who run barefoot through the streets and are allergic to light, but who, during the nighttime hours, manage to feed on just about everyone else.

Neville is the last uninfected man alive in New York City, where we first encounter him hunting deer in the abandoned and overgrown streets. He is the very image of the lonely frontiersman, with a healthy respect for nature and the survival skills to avoid being caught by the bands of zombie savages who emerge at night. But Neville is also a brilliant scientist, with a well-equipped laboratory in which he works tirelessly in solitude to develop a serum that will kill the virus. When he identifies a promising compound, he captures a female zombie to use as a test subject. A wall of photos of previous test subjects 


\section{MONOGRAPH}

Word of science

who have died in his care suggests that he has been doing this for quite some time.

In the end, Neville discovers a cure, but to preserve it, sacrifices himself in a suicide run at the zombies who have swarmed his laboratory; a martyrdom that saves an uninfected woman and child who are travelling through the city and who promise to get the cure out to the few remaining human survivors. With a beatific «I'm listening» that indicates his renewed faith in God, he dedicates his death to the restoration of humanity and becomes the titular «legend». Scientists around the world can feel proud of their heroic frontier avatar in the heavily muscled, courageous, self-sacrificing Neville.

So according to this narrative, the scientist can be either a bumbling dangerous fool or a heroic, adventurous savior. Our contemporary fear of viral apocalypse is thus tied to our ambivalence about scientists, who can be figures of scorn or heroworship, both the cause of the coming catastrophe and the source of our salvation.

\section{'I AM LEGEND’ ALTERNATE ENDING: THE SELF- REFLEXIVE SCIENTIST}

However, what is most interesting about this film is not the potential versatility of the figure of the scientist, but that a more complicated representation was cut from the official version. I am legend did not always have the ending described above. In fact, it started with a very different narrative arc
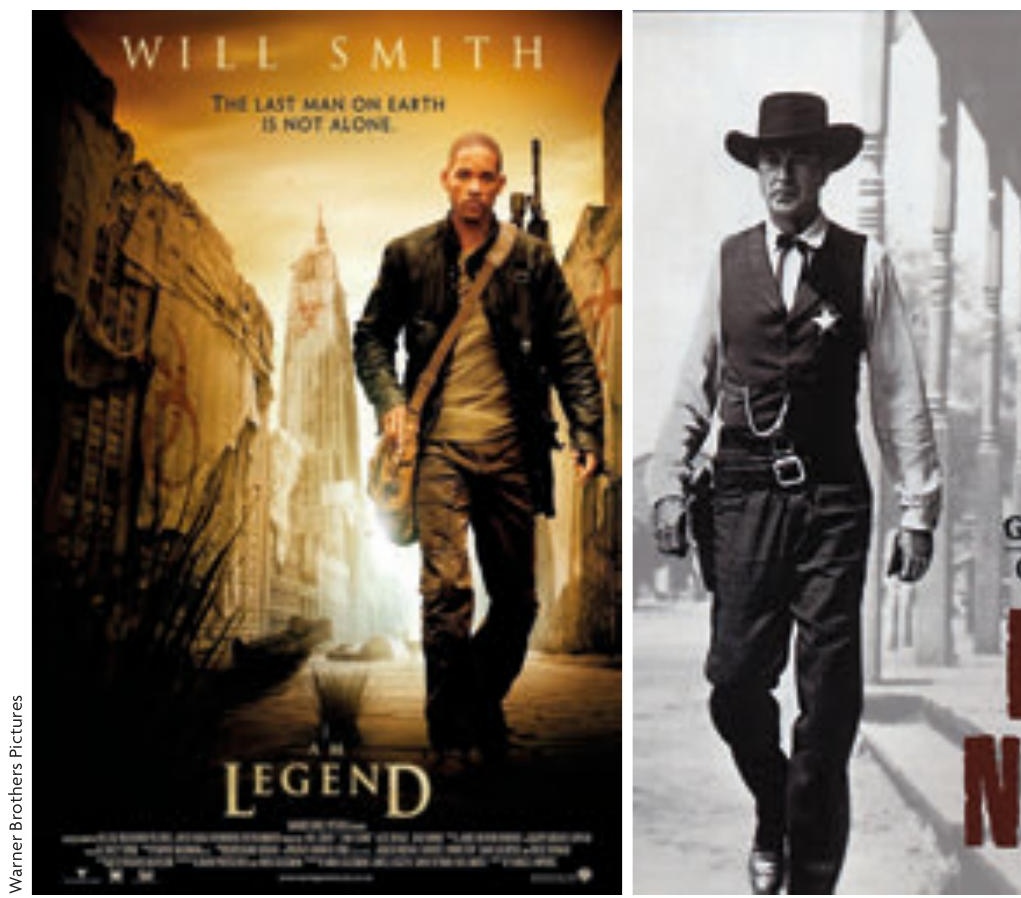

The contemporary zombie movie does bear some striking similarities to the classic western film, with gun-toting heroes facing off against hostile savages. On the left, the cover of I am legend (2007). On the right, the cover of the DVD edition of High Noon.

An alternate ending was shot for I am legend, but it did not test well with audiences, so it was changed. In that version, the main character respected the Dark Seekers' lives.

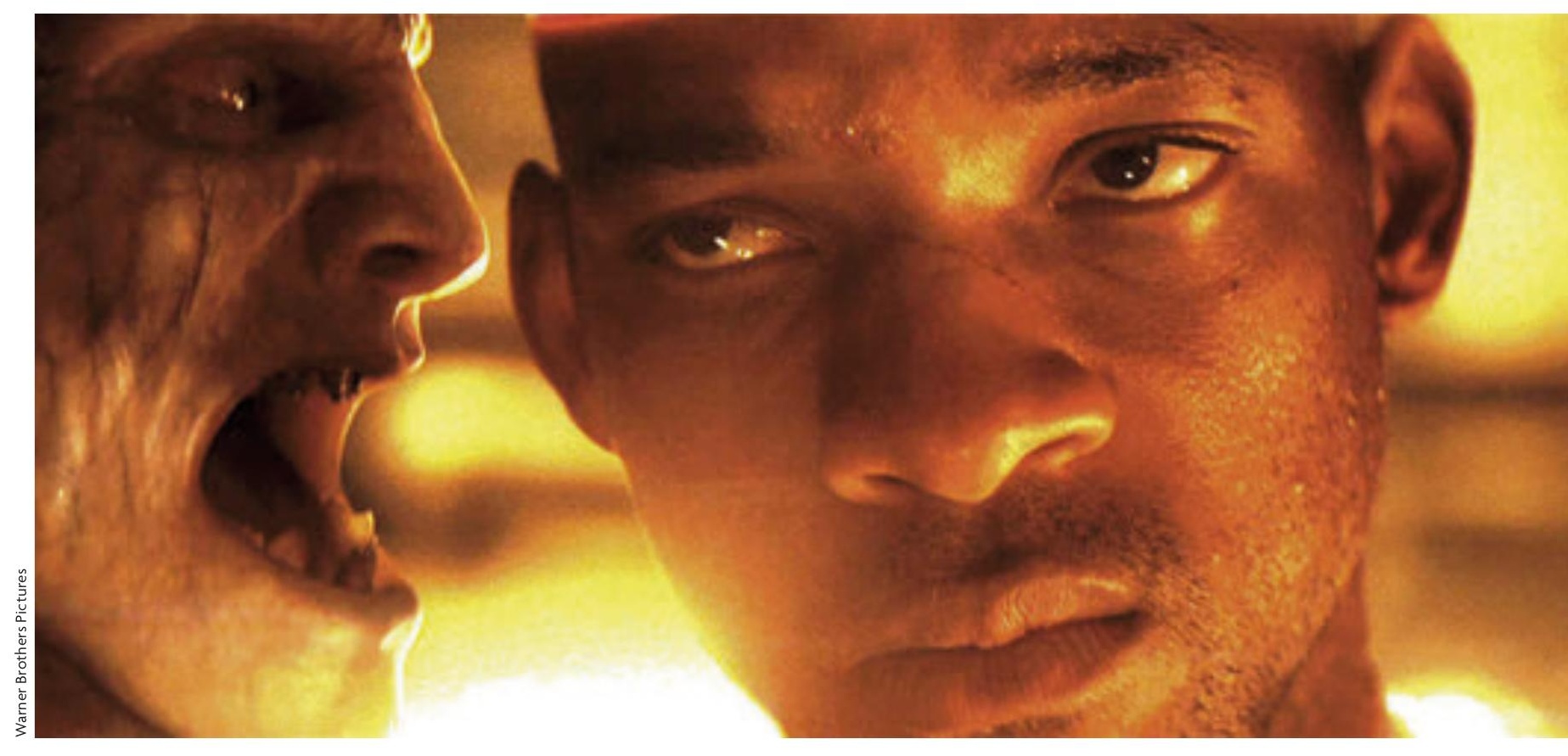


